\title{
Efforts to Improve Students' Attitudes with the Problem Based Learning Model
}

\author{
Roro Hoyi ${ }^{1 *}$, Astalini², Dwi Agus Kurniawan ${ }^{3}$ \\ 1,2,3 Pendidikan Fisika, Universitas Jambi, Muaro Jambi, Indonesia \\ *Corresponding author: rorohoyi3@gmail.com
}

\section{Abstrak}

Masih banyak siswa yang mengalami kesulitan dalam mempelajari mata pelajaran fisika. Hal ini berdampak pada rendahnya hasil belajar fisika siswa. Tujuan dari penelitian ini adalah untuk menganalisis model pembelajaran fisika berbasis masalah. Jenis penelitian ini adalah penelitian tindakan kelas. Penelitian ini dilaksanakan dalam 2 siklus yang terdiri dari perencanaan, pelaksanaan tindakan, observasi, dan refleksi. Subjek uji adalah 15 siswa. Metode yang digunakan untuk mengumpulkan data adalah observasi, wawancara, angket dan tes. Instrumen yang digunakan untuk mengumpulkan data adalah kuesioner. Teknik analisis data yang digunakan adalah analisis deskriptif kualitatif dan kuantitatif. Hasil belajar yaitu hasil belajar menunjukkan bahwa pada siklus I hasil belajar siswa adalah 55\%. Sedangkan siklus II hasil belajar siswa sebesar 80\%. Dari hasil tersebut dapat disimpulkan bahwa hasil belajar fisika dapat ditingkatkan melalui model pembelajaran berbasis masalah. Implikasi dari penelitian ini adalah model pembelajaran berbasis masalah dapat digunakan oleh guru dalam meningkatkan sikap siswa dalam pembelajaran.

Kata kunci: Fisika, Model Pembelajaran Berbasis Masalah

\section{Abstract}

There are still many students who have difficulty in learning physics subjects. This affects students' low physics learning outcomes. The purpose of this study is to analyze the problem-based learning model of physics. This type of research is classroom action research. This research was carried out in 2 cycles consisting of planning, implementing actions, observing, and reflecting. The test subjects were 15 students. The methods used to collect data are observation, interviews, questionnaires and tests. The instrument used to collect data is a questionnaire. The technique used to analyze the data is descriptive qualitative and quantitative analysis. The results of the study, namely the results of the study showed that in the first cycle the learning outcomes of students were $55 \%$. While the second cycle of student learning outcomes of $80 \%$. From these results, it can be concluded that physics learning outcomes can be improved through problem-based learning models. The implication of this research is that the problem-based learning model can be used by teachers in improving students' attitudes in learning.

Keywords: Physics, Problem-Based Learning Model

$\begin{array}{ll}\text { History: } & \text { Publisher: Undiksha Press } \\ \text { Received : March 20, } 2021 & \text { Licensed: This work is licensed under } \\ \text { Revised : March 21, } 021 & \text { a Creative Commons Attribution 3.0 License } \\ \text { Accepted : April 10, 2021 } & \text { CC } \\ \text { Published : April 25, 2021 } & \text { SA }\end{array}$

\section{Introduction}

Physics is a science that studies the behavior and properties of matter in very diverse fields, ranging from the sub-microscopic particles that make up all matter to the behavior of the material universe as a whole (Fitri, 2016; Kasih, 2017). So there are still many students who do not understand physics and do not like the subject (Handayani, 2017; Sari, Koto, \& Sakti, 2019). All of that because of the likes or dislikes that will affect the physics learning process . In addition, one of the factors that influence the learning process is attitude. Students' attitudes are a reflection of their students' thoughts. If the students think that a physics very difficult, then it will have an impact on his attitude during the process of learning takes place (Diani \& Niken, 2018; Nugroho \& Hendayana, 2011). Based on observations made by researchers in class XI IPA 1 MAN Batang Hari, some students are not interested in physics, because they think physics is difficult. In addition, teachers still apply 
the model in accordance with the 2013 curriculum in physics learning, but it is not optimal in applying it. The physics learning process is still teacher-centered, where the teacher only gives questions and assignments. Not all students understand the assignments given. So many students do not do assignments. If students do not do assignments, students will play games and students do not care about the lesson. The reason students don't care about physics is because students don't like physics. This shows that the attitude of students in class XI IPA 1 on physics subjects is in the low category.

Based on the results of interviews conducted with physics subject teachers in class XI IPA 1 MAN Batang Hari, the teacher applies a model that is in accordance with the 2013 curriculum. The 2013 curriculum is required for students to play an active role, but most students do not play an active role in learning activities. who are silent from the beginning to the end of the learning process and students talk to their classmates during the group discussion learning process. During the physics learning process there are still students who are always late in doing assignments on time. Based on the results of interviews conducted by researchers with students in class XI IPA 1 MAN Batang Hari, some students did not like physics. Physics is considered difficult because there are many formulas that must be explained. Students also tend to get bored of studying physics, because in the learning process the teacher only explains briefly and takes notes and then gives questions or assignments (Noor \& Wilujeng, 2015; Putra \& Sudarti, 2015). If given a question or assignment, students choose not to do it because of the difficulty in answering physics questions, students are just silent and are allowed to enter and leave the class in the physics learning process. The reason for the attitude of students not caring about physics is because students do not like physics lessons, students are not interested in physics lessons, so that it affects student responses in the physics learning process.

Therefore, efforts are needed to improve the learning process through learning that improves attitudes. These improvements can be made with a learning model (Awaludin, Wibawa, \& Winarsih, 2020; Jalil, 2016; Shofiyah, 2018). The learning model is a plan that is used as a guide in planning teaching and learning activities (Dewi, Kusmariyatni, \& Margunayasa, 2016; Durnali, 2020; Suari, 2018). The learning model is a conceptual framework which describes a systematic procedure in organizing learning experiences to achieve certain learning objectives (Febriana, 2011; Gunantara, Suarjana, \& Riastini, 2014; Siswanto, 2012). The learning model that applied the teachers to improve the attitude of students is by using a model of learning Problem based learning. The learning model of problem-based learning is a learning model that drives students learn actively to solve the problems complex in situations realistic (Asyari, Henie, Muhdhar, \& Ibrahim, 2016; Kamisa, 2016; Yuniawardani \& Mawardi, 2018). Students expressed that they were pleased to learn the model of problem -based learning, besides being able to understand the material being taught, students can also work together to solve a problem that is given (Devi \& Bayu, 2020; Diah \& Riyanto, 2016; Syairani \& Tarigan, 2015). Activity solving problems that are given in the activities of the learning will be more meaningful for students of the information notified directly (Kristinawati, Susilo, \& Gofur, 2018; Rozhana \& Harnanik, 2019). That is activity solving the problem which is provided in the activities of the learning will be more meaningful for the students of the information that is notified directly. An increase in the attitude of scientific participants of students who are taught by a model of learning Problembased learning is better compared with those students who are taught by lecture method (Alfi, Sumarmi, \& Amirudin, 2016; Rahmadani \& Anugraheni, 2017). Learning by using a problem-based learning learning model focusing the students in order to solve the problem, thus giving experience directly the means. Based on the description above can be concluded that learning model of problem-based learning is a model that requires students contribute actively in memecahakan problems that have objectives that students gain experience, 
improve attitudes and skills of the students' science (Kimianti \& Prasetyo, 2019; Pramana, Jampel, \& Pudjawan, 2020).

Previous research findings stated that the problem-based learning model could increase students' enthusiasm for learning (Defiyanti \& Sumarni, 2019; Sofyan, 2016; Umbara, Sujana, \& Negara, 2020). Other research also states that problem-based learning models can improve student learning outcomes (Anugraheni, 2018; Gunantara et al., 2014; Wyness \& Dalton, 2018). Based on some research relevant to earlier has not been there that examines the application of the model of learning problem-based learning on the attitudes of students in the eyes of the lessons of physics. In which the research is relevant previously only examine the application of the model of learning problem -based learning to the learning outcomes of students in physics and scientific attitude of students. So that the novelty of this research is the application of the problem based learning model to students' attitudes in physics subjects . It aims to improve students' attitudes towards physics subjects. The purpose of this study is to analyze the problem-based learning model in Physics subjects. It is hoped that this model can help students learn so that they can improve student learning outcomes in Physics.

\section{Methods}

This research uses Classroom Action Research (CAR). Kurt Lewin's model has become a reference for various action research models because Kurt Lewin was the first to introduce action research. The main components in Kurt Lewin's action research are planning (planning), action (act), observations (observing), reflection (reflecting). The relationship between the four main concepts is illustrated by the following diagram. The methods used to collect data are observation, interviews, questionnaires and test. The instrument used to collect data is a questionnaire.

Each cycle consists of 4 stages which include planning, implementation, observation and reflection. At the planning stage there are several steps, namely: planning a learning model that will be applied in learning activities, namely problem based learning on thermodynamics physics subjects, Develop learning scenarios by making lesson plans for the problem base learning model that will be applied, Adopt an attitude questionnaire for the student's initial attitude observation sheet, prepare questions for evaluating thermodynamics material that will be tested in writing to students, conditioning the classroom, plan the division of groups of students, namely 1 group consisting of 5 students. At this stage of implementation, it is adjusted to the method that has been planned, namely the problem base learning model. For the activity stage, each model follows the existing syntax. During the process of implementing the learning process using the problem base learning model, there were observers who observed using the observation format that had been adopted by the researcher. After knowing the results then discussed with the physics subject teacher to solve problems that occurred during the action, The reflection stage consists of several processes, namely: seeing the obstacles in the implementation of learning by observation, evaluate the actions that have been taken based on the results of observations, hold a meeting to discuss the results of the evaluation of the learning model scenario and others, If the results have gone well, it will be maintained, if it has not gone well, the implementation of the actions will be improved according to the results of the evaluation in the next cycle.

After evaluating the first action, the second action is carried out. Researchers carry out the teaching and learning process using a problem base learning model in physics subjects on thermodynamic material. The activity carried out at this stage is the development of an action plan II by carrying out actions to further increase the enthusiasm of students' learning in the application of the problem base learning model in thermodynamics physics subjects to 
improve students' attitudes. The researcher processed the observation data when the learning model action took place, discussed the second action that had been taken, and noted weaknesses that were not in accordance with the scenario and those that were not in accordance with the expected response. The reflection stage consists of several processes, namely: evaluation test of learning model problem base learning on thermodynamic physics subject at MAN Batang Hari, analyze the results of observations in order to get an idea of how the impact of the actions taken, and what things need to be improved so that the results of the reflection of the activities carried out are obtained. The indicator of research success is if the results of learning physics are in the high category, namely reaching the $70 \% \mathrm{KKM}$ standard. The technique used to analyze the data is descriptive qualitative and quantitative analysis.

\section{Results and Discussion}

This research was conducted in two cycles, namely cycle I and cycle II. In the first cycle it was carried out in 2 meetings and in the second cycle it was carried out in 2 meetings. From the two cycles, it can be seen how far the success rate of students in implementing actions in learning physics through problem based learning learning models. At the end of each cycle I and cycle II , evaluation and reflection are carried out related to the improvement of students' physics learning outcomes. Based on the results of tests given to students at the end of the first cycle, the obtained results of quantitative descriptive analysis of test score results to learn physics of students in class XI M IPA1 SMA Muaro of the concepts of thermodynamics are taught in the first cycle during two meetings through learning model problem based learning in the learning process can be seen in the following table:

Table 1. Analysis of Success Indicators

\begin{tabular}{clcc}
\hline No & \multicolumn{1}{c}{ Observed variables } & amount & Percentage\% \\
\hline 1. & Total students & 15 & $100 \%$ \\
2. & Total score of the average student attitude & 7 & $46.67 \%$ \\
& assessment & 2 & $13.3 \%$ \\
3. Number of successful students & 13 & $86.67 \%$ \\
4. Number of unsuccessful students & & & \\
\hline
\end{tabular}

Based on table 1. it can be seen that the number of students is 15 people with a percentage of $100 \%$, the average score for the assessment of student attitudes by the observer is 7 with a percentage of $46.67 \%$, the number of students who succeed is 2 with a percentage of $13.3 \%$ and at the number of students who did not succeed were 13 people with a percentage of $86.67 \%$. Based on the data obtained, it can be analyzed students' attitudes towards physics subjects which consist of several indicators, including: cooperation, responsibility, tolerance, and discipline. Based on table 3, students' attitudes towards physics subjects using the problem-based learning model are categorized as not good. In the indicator of cooperation, the percentage of students is $43 \%$. While the responsibility indicator is $45 \%$, the tolerance indicator is $45 \%$ and the discipline indicator is $42 \%$. Based on the results of tests given to students at the end of the second cycle, the obtained results of quantitative descriptive analysis to score the results of studying the physics of students in class XI IPA1 Man Batang day with matter wave mechanics of materials which are taught through an approach model of learning problem base learning in the learning process on cycle II can be seen in the following Table 2. 
Table 2. Indicators of Student Attitude Success

\begin{tabular}{llll}
\hline No & \multicolumn{1}{c}{ Observed variables } & \multicolumn{1}{c}{ amount } & \multicolumn{1}{c}{ Percentage \% } \\
\hline 1. & Total students & 15 & $100 \%$ \\
2. & The average number of students' attitude & 12.33 & $82.2 \%$ \\
3. & assessment scores & & \\
4. & Number of successful students & 15 & $100 \%$ \\
\hline
\end{tabular}

Based on Table 2 it can be seen that the number of students is 15 people with a percentage of $100 \%$, the average number of students' attitudes towards physics is 12.33 , the number of students who are successful is 15 with a percentage of $100 \%$ and the number of students who are not successful is 0 people with $0 \%$ percentage. Based on the data obtained can be analyzed students' attitudes towards physics which consists of several indicators, including: cooperation, sole responsibility, tolerance, and discipline. As the result of observation of the attitude of the students towards the eyes of physics can be seen in Table 3 .

Table 3. Analysis of Attitudes Towards Physics Subjects

\begin{tabular}{lcc}
\hline \multirow{2}{*}{ Indicator } & \multicolumn{2}{c}{ Cycle II } \\
\cline { 2 - 3 } & Score & Percentage \\
\hline working together & 47 & $78 \%$ \\
responsibility responsibility & 46 & $77 \%$ \\
Tolerance & 45 & $75 \%$ \\
Discipline & 47 & $78 \%$ \\
\hline Total & $\mathbf{1 4 9}$ & \\
\hline
\end{tabular}

In Table 3 can be seen that the attitude of the students in the subjects of physics in class XI by using a model of learning problem base learning increased cooperation is the indicator the percentage of students $78 \%$. Furthermore, the indicator of student attitude responsibility is $77 \%$ and the percentage of students' tolerance indicator is $75 \%$. Then on the indicator of student attitude discipline that is in the percentage of $78 \%$. In the first cycle of research, only 15 students became respondents from 16 students, because one student was sick when the cycle test was carried out. At the end of cycle 1 students were given questions and divided into groups of 5 people. Each group was given a question in the form of 5 questions about thermodynamic material. After being analyzed, it turns out that the results obtained have not met the indicators of success . Because in doing group assignments, students do not work well together. This happens because in the implementation of the action there are several shortcomings. The shortcomings are as follows: 1 ) The time provided for working on the LKPD is limited. 2 ) Students who are active in working on LKPD are still lacking. Thus, the research continued to cycle II by making various improvements as follows : 1) increasing the time to work on LKPD. 2) increase the activity of students by providing small experiments according to the learning material. 2) add videos related to learning materials. 3) make PPT more attractive.

After the implementation of the second cycle of actions is completed, then at the end of the meeting a second cycle test is carried out by giving a physics learning outcome test to see the students' physics learning outcomes. The evaluation results obtained from cycle II are conclusions that describe an increase in physics learning outcomes for students in class XI IPA 1 SMA MAN 5 Batang Hari after being taught through a problem-based learning model approach on a mechanical wave of materials with the percentage of students' learning completeness being $80 \%$. or as many as 11 students who completed from 15 students, these 
results have met the indicators of success, so that the implementation of the action only reached cycle II.

\section{Discussion}

In cycle 1 , it is in accordance with the learning objectives. In the learning process, some students did not participate and some students had followed the procedure, it was just that there were still some students who did not pay attention to learning well. Based on the researcher's observations, the observed student activities were not as expected. Meanwhile, according to the teacher's own observations, there are still some students who are busy chatting with their friends next to them so that the quality of learning is reduced.

Furthermore, in cycle II the physics learning process carried out can be categorized as good. The attitude of students when the teacher explained using power point and video media, students were very enthusiastic in learning and students became focused on the infocus screen. Learning video media can help students understand learning materials easily (Andriyani \& Suniasih, 2021; Asnur \& Ambiyar, 2018; Utari, 2016). When the teacher asks questions related to the material being studied, some students can answer these questions. Problem based learning learning models can also activate students in learning (Asriningtyas, Kristin, \& Anugraheni, 2018; Lukitasari, Purnamasari, Utami, \& Sukri, 2019). The results in the second cycle increased by using the problem based learning model. At the orientation stage, students listen carefully to what the teacher explains. Students also respond to questions that the teacher gives. This learning model can create a pleasant learning atmosphere (Hadi \& Rahmantika, 2016; Jahro \& Ridho, 2015). On indicators of cooperative attitude, all students work well together, students can observe the experiment together. Student discipline has increased, namely students collect on time. All students complete group assignments by working together and distributing assignments fairly (Ningsih, Arif Hidayat, \& Kusairi, 2018; Saguni, 2013; Winursiti, 2017).

Furthermore, students are responsible for doing group assignments well. Presenting group assignments well. Furthermore, on the indicator of tolerance, students already respect the opinions of their friends so that the learning process can run smoothly. The use of Problem Based Learning learning models in physics subjects can improve student attitudes, especially on thermodynamics material; this proves the success of implementation and student learning outcomes in learning. class XI IPA 1 MAN 5 Batang. This learning model can make students appreciate the opinions of their friends more (Fitria \& Idriyeni, 2017; Haryati, 2017). In addition, this learning model can create an active learning atmosphere so that students can enjoy learning (Daniel, 2016; Kimianti \& Prasetyo, 2019; Sumitro, Setyosari, \& Sumarmi, 2017). The findings of previous studies also state that the problembased learning model can increase student enthusiasm and student activity in learning (Gunantara et al., 2014; Shofiyah, 2018; Wyness \& Dalton, 2018). Other research findings also state that the problem-based learning model can increase students' learning motivation siswa (Fitriyanti, Farida, \& Zikri, 2020; Hadi \& Rahmantika, 2016). This research implies that teachers can apply the problem-based learning model to create a pleasant learning atmosphere and improve student learning outcomes.

\section{Conclusion}

Problem-based learning models can improve student attitudes because students pay attention to the subject matter taught by the teacher, students are more disciplined and responsible for group assignments, and students work on group assignments by working together. It is recommended for teachers to use a problem-based learning model so that it can increase students' enthusiasm in learning. 


\section{References}

Alfi, C., Sumarmi, S., \& Amirudin, A. (2016). Pengaruh Pembelajaran Geografi Berbasis Masalah Dengan Blended Learning Terhadap Kemampuan Berpikir Kritis Siswa SMA. Jurnal Pendidikan Teori, Penelitian, Dan Pengembangan, 4(1). https://doi.org/http://dx.doi.org/10.17977/jp.v1i4.6203.

Andriyani, N. L., \& Suniasih, N. W. (2021). Development Of Learning Videos Based On Problem-Solving Characteristics Of Animals And Their Habitats Contain in Science Subjects On 6th-Grade. Journal of Education, 5(1), 37-47. https://doi.org/http://dx.doi.org/10.23887/jet.v5i1.32314.

Anugraheni. (2018). Meta Analisis Model Pembelajaran Problem Based Learning dalam Meningkatkan Keterampilan Berpikir Kritis di Sekolah Dasar. A Journal of Language, Literature, Culture, and Education, 14(1). https://doi.org/http://dx.doi.org/10.19166/pji.v14i1.789.

Asnur, \& Ambiyar. (2018). Penerapan Pembelajaran Menggunakan Media Video Pada Mata Kuliah Tata Boga II. Jurnal Mimbar Ilmu, 23(3). https://doi.org/http://dx.doi.org/10.23887/mi.v23i3.16435.

Asriningtyas, A. N., Kristin, F., \& Anugraheni, I. (2018). Penerapan Model Pembelajaran Problem Based Learning Untuk Meningkatkan Kemampuan Berpikir Kritis Dan Hasil Belajar Matematika Siswa Kelas 4 SD. JIPMat. https://doi.org/10.26877/jipmat.v3i1.2226.

Asyari, M., Henie, M., Muhdhar, I. Al, \& Ibrahim, H. S. (2016). Improving critical thinking skills through the integration of problem based learning and group investigation. International Journal for Lesson and Learning Studies, 5(1), 36-44. https://doi.org/http://dx.doi.org/10.1108/IJLLS-10-2014-0042.

Awaludin, Wibawa, \& Winarsih. (2020). Integral Calculus Learning Using Problem Based Learning Model Assisted by Hypermedia-Based E-Book. Jurnal Pendidikan Indonesia, 9(2). https://doi.org/http://dx.doi.org/10.23887/jpi-undiksha.v9i2.23106.

Daniel, E. (2016). The Usefulness of Qualitative and Quantitative Approaches and Methods in Researching Problem-Solving Ability in Science Education Curriculum. Journal of Education and Practice, 7(15), 91-100. https://doi.org/2222-288X.

Defiyanti, \& Sumarni. (2019). Analisis Kemampuan Berpikir Kritis Setelah Penerapan Problem Based Learning Berbantuan Lembar Kerja Peserta Didik Bermuatan Etnosains. Jurnal Phenomenon Pendidikan MIPA, 9(2), 206-218. https://doi.org/http://dx.doi.org/10.21580/phen.2019.9.2.4200.

Devi, P. S., \& Bayu, G. W. (2020). Berpikir Kritis dan Hasil Belajar IPA Melalui Pembelajaran Problem Based Learning Berbantuan Media Visual. MIMBAR PGSD Undiksha, $8(2)$, $238-252$. https://doi.org/http://dx.doi.org/10.23887/jjpgsd.v8i2.26525.

Dewi, Kusmariyatni, \& Margunayasa. (2016). Pengaruh Model Pembelajaran Learning Cycle 5E Terhadap Hasil Belajar IPA Siswa Kelas V SD. Mimbar PGSD Undiksha, 4(1). https://doi.org/http://dx.doi.org/10.23887/jjpgsd.v4i1.6658.

Diah, \& Riyanto. (2016). Problem-Based Learning Model In Biology Education Courses To Develop Inquiry Teaching Competency Of Preservice Teachers. Cakrawala Pendidikan, 35(1), 47-57. https://doi.org/https://doi.org/10.21831/cp.v1i1.8364.

Diani, R., \& Niken, S. H. (2018). Flipbook Berbasis Literasi Islam : Pengembangan Media Pembelajaran Fisika dengan 3d Pageflip Professional Flipbook Based On Islamic Literacy: The Development Of Physics Learning Media Using 3d Pageflip Professional." 4(2):234-44. Jurnal Inovasi Pendidikan IPA, 4(2). https://doi.org/https://doi.org/10.21831/jipi.v4i2.20819. 
Durnali, M. (2020). The effect of self-directed learning on the relationship between selfleadership and online learning among university students in Turkey. Tuning Journal for Higher Education, 8(1), 129-165. https://doi.org/http://dx.doi.org/10.18543/tjhe8(1)-2020pp129-165 Received.

Febriana, A. (2011). Penerapan Model Pembelajaran Kooperatif Tipe Make A Match Untuk Meningkatkan Kualitas Pembelajaran IPS Siswa Kelas V SDN Kalibanteng Kidul 01 Kota Semarang. Kependidikan Dasar, https://doi.org/https://doi.org/10.15294/kreatif.v1i2.1678.

Fitri, F. (2016). Peningkatan Kemandirian Mahasiswa Pendidikan Fisika Pada Mata Kuliah Mekanika Melalui Metode Reciprocal Teaching. Jurnal Pendidikan Fisika, 4(1). https://doi.org/http://dx.doi.org/10.24127/jpf.v4i1.391.

Fitria, Y., \& Idriyeni, I. (2017). Development of Problem-Based Teaching Materials for The Fifth Graders of Primary School. Jurnal Ta'dib, 20(2), 99-106. https://doi.org/http://dx.doi.org/10.31958/jt.v20i2.747.

Fitriyanti, F., Farida, \& Zikri, A. (2020). Peningkatan Sikap dan Kemampuan Berpikir Ilmiah Siswa Melalui Model PBL di Sekolah Dasar. Jurnal Basicedu, 4(2). https://doi.org/https://doi.org/10.31004/basicedu.v4i2.376.

Gunantara, G., Suarjana, M., \& Riastini, P. N. (2014). Penerapan model pembelajaran problem based learning untuk meningkatkan kemampuan pemecahan masalah matematika siswa kelas V. Jurnal Mimbar PGSD Undiiksha, 2(1). https://doi.org/http://dx.doi.org/10.23887/jjpgsd.v2i1.2058.

Hadi, \& Rahmantika. (2016). Penerapan Pembelajaran Problem Based Learning (PBL) untuk Meningkatkan Hasil Belajar Matematika Siswa Kelas IV Sekolah Dasar. Jurnal Profesi Pendidikan Dasar, $\quad 3(2), \quad$ 84-91. https://doi.org/https://doi.org/10.23917/ppd.v3i2.2925.

Handayani, R. D. (2017). Analisis Motivasi Intrinsik Dan Ekstrinsik mahasiswa Calon Guru Fisika. Jurnal Kependidikan: Penelitian Inovasi Pembelajaran, 1(2), 320-333. https://doi.org/https://doi.org/10.21831/jk.v1i2.8449.

Haryati, Y. (2017). Model Problem Based Learning Membangun Kemampuan Berpikir Kritis Siswa Sekolah Dasar. Jurnal Cakrawala Pendas, 3(2), 57-63. https://doi.org/http://dx.doi.org/10.31949/jcp.v3i2.596.

Jahro, S., \& Ridho, D. (2015). Penerapan Model Problem Based Learning Menggunakan Media Exe Learning untuk Meningkatkan Hasil Belajar dan Kerjasama Siswa Pada Materi Hidrokarbon. Jurnal Pendidikan Kimia, 7(3), 80-86. https://doi.org/https://doi.org/10.24114/jpkim.v7i3.4261.

Jalil, M. (2016). Pengembangan Pembelajaran Model Discovery Learning Berbantuan Tips Powerpoint Interaktif Pada Materi Interaksi Makhluk Hidup Dengan Lingkungan. Refleksi Edukatika: Jurnal Ilmiah Kependidikan, 6(2). https://doi.org/https://doi.org/10.24176/re.v6i2.604.

Kamisa, A. (2016). Penerapan Model Problem Based Learning Dalam Pembelajaran Sejarah Untuk Meningkatkan Motivasi Dan Prestasi Belajar Siswa Kelas XI IPS 1 Sman 1 Butar Sulawesi Tengah. Jurnal Pendidikan Dan Sejarah, 12(1). https://doi.org/https://doi.org/10.21831/istoria.v12i1.9542.

Kasih, F. (2017). Pengembangan Film Animasi dalam Pembelajaran Fisika pada Materi Kesetimbangan Benda Tegar di SMA. Jurnal Keguruan Dan Ilmu Tarbiyah, 2(1), 4147. https://doi.org/https://doi.org/10.24042/tadris.v2i1.1737.

Kimianti, \& Prasetyo. (2019). Pengembangan E-Modul IPA Berbasis Problem Based Learning Untuk Meningkatkan Literasi Sains Siswa. Kwangsan Jurnal Teknologi Pendidikan, 7(2). https://doi.org/https://doi.org/10.31800/jtp.kw.v7n2.p91--103.

Kristinawati, E., Susilo, H., \& Gofur, A. (2018). ICT Based-Problem Based Learning on 
Students' Cognitive Learning Outcomes. Jurnal Pendidikan Sains, 6(2), 38-42. https://doi.org/http://dx.doi.org/10.17977/jps.v6i2.11683.

Lukitasari, Purnamasari, Utami, \& Sukri. (2019). Blended-Problem-Based Learning: How its impact on students' critical thingking skills? Jurnal Pendidikan Biologi Indonesia, 5(3), 425-434. https://doi.org/https://doi.org/10.22219/jpbi.v5i3.10048.

Ningsih, P. R., Arif Hidayat, \& Kusairi, S. (2018). Penerapan Problem Based Learning Untuk Meningkatkan Kemampuan Berpikir Kritis Dan Hasil Belajar Siswa Kelas III. Jurnal Pendidikan, $3(12)$, 1587-1593. https://doi.org/http://dx.doi.org/10.17977/jptpp.v3i12.11799.

Noor, F. M., \& Wilujeng, I. (2015). Pengembangan Ssp Fisika Berbasis Pendekatan Ctl Untuk Meningkatkan Keterampilan Proses Sains Dan Motivasi Belajar. Jurnal Inovasi Pendidikan Fisika,

1(1). https://doi.org/https://doi.org/10.21831/jipi.v1i1.4534.

Nugroho, L. A., \& Hendayana, S. (2011). Penerapan Lesson Study Berbasis Sekolah Untuk Melaksanakan Supervisi Akademik Pembelajaran Fisika Di Sma1. Jurnal Penelitian Pembelajaran Matematika, 2(1). https://doi.org/https://doi.org/10.26877/jp2f.v2i1/April.124.

Pramana, Jampel, \& Pudjawan. (2020). Meningkatkan Hasil Belajar Biologi Melalui EModul Berbasis Problem Based Learning. Jurnal Edutech Undiksha, 8(2), 18-32. https://doi.org/http://dx.doi.org/10.23887/jeu.v8i2.28921.

Putra, P. D. A., \& Sudarti. (2015). Pengembangan Sistem E-Learning untuk Meningkatkan Keterampilan Berpikir Kritis Mahasiswa Pendidikan Fisika. Jurnal Fisika Indonesia, 19(55), 45-48. https://doi.org/https://doi.org/10.22146/jfi.24373.

Rahmadani, \& Anugraheni, I. (2017). Peningkatan aktivitas belajar matematika melalui pendekatan problem based learning bagi siswa kelas 4 SD. Scholaria: Jurnal Pendidikan Dan Kebudayaan, 7(3), 241-250. https://doi.org/https://doi.org/10.24246/j.scholaria.2017.v7.i3.p241-250.

Rozhana, K. M., \& Harnanik, H. (2019). Lesson Study dengan Metode Discovery Learning dan Problem Based Instruction. Intelegensi: Jurnal Ilmu Pendidikan, 1(2). https://doi.org/https://doi.org/10.33366/ilg.v1i2.1355.

Saguni, F. (2013). Efektivitas Metode Problem Based Learning, Cooperative Learning Tipe Jigsaw, Dan Ceramah Sebagai Problem Solving Dalam Matakuliah Perencanaan $\begin{array}{lll}\text { Pembelajaran. } \quad \text { Cakrawala } & \text { Pendidikan, }\end{array}$ https://doi.org/https://doi.org/10.21831/cp.v0i2.1478.

Sari, P. E., Koto, I., \& Sakti, I. (2019). Hubungan Kecerdasan Intelektual Dan Hasil Belajar Fisika Siswa Kelas XI IPA SMA. Jurnal Kumparan Fisika, 2(1). https://doi.org/https://doi.org/10.33369/jkf.2.1.49-56.

Shofiyah, F. (2018). Model Problem Based Learning (PBL) dalam Melatih Scientific Reasoning Siswa. Jurnal Penelitian Pendidikan IPA, 3(1), 33-38. https://doi.org/http://dx.doi.org/10.26740/jppipa.v3n1.p33-38.

Siswanto, B. T. (2012). Pengaruh Model Penyelenggaraan Work-Based Learning Rolling Terpadu Terhadap Aspek-Aspek Kualitas Hasil Belajar. Jurnal Pendidikan Teknologi Dan Kejuruan, 21(1). https://doi.org/https://doi.org/10.21831/jptk.v21i1.3341.

Sofyan. (2016). Pembelajaran Problem Based Learning dalam Implementasi Kurikulum 2013 di SMK. Jurnal Pendidikan Vokasi, 6(3), 260-271. https://doi.org/https://doi.org/10.21831/jpv.v6i3.11275.

Suari. (2018). Penerapan Model Pembelajaran Problem Based Learning Untuk Meningkatkan Motivasi Belajar IPA. Jurnal Ilmiah Sekolah Dasar, 2(3), 241-247. https://doi.org/http://dx.doi.org/10.23887/jisd.v2i3.16138.

Sumitro, A. H., Setyosari, P., \& Sumarmi. (2017). Penerapan Model Problem Based Learning 
meningkatkan Motivasi dan Hasil Belajar IPS. Jurnal Pendidikan:Teori, Penelitian,

Dan Pengembangan,

12(1). https://doi.org/http://dx.doi.org/10.17977/jptpp.v2i9.9936.

Syairani, \& Tarigan. (2015). Efektivitas Model Pembelajaran Berbasis Masalah (Problem Based Learning) Terhadap Hasil Belajar Siswa Pada Sub Materi Ekosistem Di Kelas X Sma Negeri 1 Percut Sei Tuan T.P. 2014/2015. Jurnal Pelita Pendidikan, 3(4). https://doi.org/https://doi.org/10.24114/jpp.v3i4.4008.

Umbara, I. A. A. P., Sujana, I. W., \& Negara, I. G. A. O. (2020). Model Pembelajaran Problem Based Learning Berbantuan Media Gambar Seri BerpengaruhTerhadap Kompetensi Pengetahuan IPS Siswa. Jurnal Mimbar Ilmu, 25(2), 13-25. https://doi.org/http://dx.doi.org/10.23887/mi.v25i2.25154.

Utari, R. (2016). Kontribusi Motivasi Belajar Dan Kebiasaan Belajar Siswa Kelas 1 Teknik Audio Video Terhadap Hasil Belajar Pada Mata Diklat Pkdle Di Smk N 1 Padang. Jurnal Ilmiah Pendidikan Teknik Elektro, l(oktober 2016), 108-114. https://doi.org/http://dx.doi.org/10.30870/volt.v1i2.2877.

Winursiti. (2017). Penerapan Model Problem Based Learning Berbantuan Reinforcement Simbolik Untuk Meningkatkan Motivasi Dan Hasil Belajar Matematika Siswa Kelas IVB di SD Lab Undiksha. Jurnal Ilmiah Sekolah Dasar, 17(2), 270-275. https://doi.org/http://dx.doi.org/10.23887/jisd.v1i4.12120.

Wyness, L., \& Dalton, F. (2018). The value of problem-based learning in learning for sustainability: Undergraduate accounting student perspectives. Journal of Accounting Education, 45, 1-19. https://doi.org/https://doi.org/10.1016/j.jaccedu.2018.09.001.

Yuniawardani, V., \& Mawardi. (2018). Peningkatan Hasil Belajar Pada Pembelajaran Matematika Dengan Model Problem Based Learning Kelas IV SD. Jurnal Riset Teknologi Dan Inovasi Pendidikan, 1(2), 24-32. https://doi.org/https://doi.org/10.31764/justek.v1i1.416. 